\title{
Genome-guided analysis of physiological and morphological traits of the fermentative acetate oxidizer Thermacetogenium phaeum
}

\author{
Dirk Oehler ${ }^{* *}$, Anja Poehlein ${ }^{2}$, Andreas Leimbach ${ }^{2}$, Nicolai Müller ${ }^{1,3}$, Rolf Daniel ${ }^{2}$, Gerhard Gottschalk ${ }^{2}$ \\ and Bernhard Schink ${ }^{1}$
}

\begin{abstract}
Background: Thermacetogenium phaeum is a thermophilic strictly anaerobic bacterium oxidizing acetate to $\mathrm{CO}_{2}$ in syntrophic association with a methanogenic partner. It can also grow in pure culture, e.g., by fermentation of methanol to acetate. The key enzymes of homoacetate fermentation (Wood-Ljungdahl pathway) are used both in acetate oxidation and acetate formation. The obvious reversibility of this pathway in this organism is of specific interest since syntrophic acetate oxidation operates close to the energetic limitations of microbial life.

Results: The genome of Th. phaeum is organized on a single circular chromosome and has a total size of 2,939,057 bp. It comprises 3.215 open reading frames of which $75 \%$ could be assigned to a gene function. The $\mathrm{G}+\mathrm{C}$ content is $53.88 \mathrm{~mol} \%$. Many CRISPR sequences were found, indicating heavy phage attack in the past. A complete gene set for a phage was found in the genome, and indications of phage action could also be observed in culture. The genome contained all genes required for $\mathrm{CO}_{2}$ reduction through the Wood-Ljungdahl pathway, including two formyl tetrahydrofolate ligases, three carbon monoxide dehydrogenases, one formate hydrogenlyase complex, three further formate dehydrogenases, and three further hydrogenases. The bacterium contains a menaquinone MQ-7. No indications of cytochromes or Rnf complexes could be found in the genome.

Conclusions: The information obtained from the genome sequence indicates that Th. phaeum differs basically from the three homoacetogenic bacteria sequenced so far, i.e., the sodium ion-dependent Acetobacterium woodii, the ethanol-producing Clostridium ljungdahlii, and the cytochrome-containing Moorella thermoacetica. The specific enzyme outfit of Th. phaeum obviously allows ATP formation both in acetate formation and acetate oxidation.
\end{abstract}

\section{Background}

Methanogenesis is the dominant process of organic matter degradation in anoxic habitats in the absence of alternative inorganic electron acceptors such as nitrate, manganese, iron, or sulfate. In the overall electron flow, acetate is the most important precursor of methane [1-6]. Acetate is converted to methane through two different pathways: either by aceticlastic methanogenesis as carried out by Methanosarcina or Methanosaeta spp. [6,7], or by syntrophic acetate oxidizers which depend on close cooperation with hydrogenotrophic methanogens $[8,9]$.

\footnotetext{
* Correspondence: Dirk.Oehler@uni-konstanz.de

'Department of Biology, Microbial Ecology, University of Konstanz, Konstanz D-78457, Germany

Full list of author information is available at the end of the article
}

In natural environments, syntrophic acetate oxidation was observed so far only in rice field soil or in subtropical lake sediments $[10,11]$. Up to this point, only six syntrophic acetate oxidizers were isolated in defined co-cultures, and all of them were obtained from anaerobic digesters [9,12-14]. Syntrophic acetate oxidation may outcompete aceticlastic methanogenesis especially at enhanced temperature, enhanced proton activity, or high acetate concentrations, which all help to improve the energetically difficult situation of syntrophic acetate oxidation [15]. Moreover, ammonia at enhanced concentrations inhibits aceticlastic methanogens and thus selects for syntrophic acetate oxidizers, e. g. in digesters treating nitrogen-rich wastes such as manure [16-20].

Thermacetogenium phaeum was isolated from sludge of an anaerobic digester run at $58^{\circ} \mathrm{C}$. It was described as

\section{Biomed Central}


a rod-shaped, spore-forming and motile bacterium able to grow with various substrates such as alcohols and methylated nitrogen compounds, and to reduce sulfate in the presence of acetate. In cooperation with Methanothermobacter thermautotrophicus, Th. phaeum degrades acetate as sole carbon source [13,21]. Enzymes of the WoodLjungdahl (CO dehydrogenase) pathway are active in cells grown either syntrophically with acetate or in pure culture with methanol [22].

In comparison with the mesophilic syntrophic acetate oxidizer Clostridium ultunense strain BS (doubling time 480-600 h) [23], Th. phaeum grows rapidly (doubling time 69-76 h) in syntrophic co-culture with acetate; 40 $\mathrm{mM}$ acetate is degraded in 24 days. Enhanced growth at elevated temperature can be explained by the concomitant gain in free energy [15]. In pure culture, C. ultunense cannot grow with methylamine or alcohols, but grows with glucose, betaine, or ethylene glycol. Th. phaeum cannot degrade these compounds [12,13].

Until now, all reported syntrophic acetate oxidizers were described as facultative homoacetogens. There are two metabolic types of homoacetogenic bacteria, the protondependent (e. g., Moorella thermoacetica, formerly Clostridium thermoaceticum) and the sodium-dependent acetogens (e. g., Acetobacterium woodii); both types use the Wood-Ljungdahl pathway for acetate formation [24]. $M$. thermoacetica contains a menaquinone- 7 and two $b$ type cytochromes [25] which are assumed to be involved in energy conservation. Enzyme assays with membrane vesicles showed that a hydrogenase, a carbon monoxide dehydrogenase, a methylene-tetrahydrofolate $\left(\mathrm{H}_{4} \mathrm{~F}\right)$ reductase, and a NADH dehydrogenase are membraneassociated and likely to be involved in energy conservation [26]. In addition, genome sequencing found indications of a membrane-bound formate hydrogenlyase system [27].

The genome of Acetobacterium woodii has recently been sequenced [28]. This bacterium can be considered as the model organism of sodium-dependent acetogens. In contrast to $M$. thermoacetica, $A$. woodii does not contain cytochromes or quinones. Rather energy appears to be conserved through a membrane-bound Rnf complex [29]. Clostridium ljungdahlii, a homoacetogenic bacterium producing ethanol as a side product, represents a third option of energy conservation: it does not contain cytochromes, is independent of sodium ions, but contains a proton translocating Rnf complex [30].

In the recent past, several genomes of strict anaerobes have been sequenced which are involved in syntrophic oxidation of butyrate (Syntrophomonas wolfei), benzoate (Syntrophus aciditrophicus), or propionate (Syntrophobacter fumaroxidans, Pelotomaculum thermopropionicum) [31-34]. In all these types of syntrophic metabolism, certain oxidation steps at comparably positive redox potentials are involved, e. g., oxidation of butyryl-CoA to
crotonyl-CoA, or of succinate to fumarate. The electrons released in these reactions require a reversed electron transport to be raised to the redox potential of the proton/ hydrogen pair (E' about $-300 \mathrm{mV}$ at $\mathrm{pH} 7.0$ and $\left[\mathrm{H}_{2}\right]$ at $10^{-4}$ atm.).

In this study, we report the analysis of the complete genome of the syntrophically acetate-oxidizing bacterium Th. phaeum, which is studied as an example of a metabolism operating close to thermodynamic limits. The results of the genome analysis could be verified in physiological experiments.

\section{Methods}

\section{Microorganism and growth conditions}

Thermacetogenium phaeum strain PB (DSM 12270) and Methanothermobacter thermautotrophicus strain TM were obtained from the DSMZ, Braunschweig, Germany. The composition of the basal medium used for all experiments has been described previously [13].

\section{Determination of growth}

Cultures were incubated at $60^{\circ} \mathrm{C}$ in $100 \mathrm{ml}$ serum bottles containing $100 \mathrm{ml}$ medium, growth was determined by measuring $\mathrm{OD}_{600}$ with a spectrophotometer (Uvikon 860, Kontron Instruments). All growth experiments were performed at least in duplicate. Substrates were added from filter-sterilized or autoclaved anoxic stock solutions to the desired final concentrations. Gases were supplied in the headspace, either as a $\mathrm{H}_{2} / \mathrm{CO}_{2}$ mixture $(80 / 20$, $\mathrm{v} / \mathrm{v}, 130 \mathrm{kPa})$ or a $\mathrm{CO} / \mathrm{CO}_{2} / \mathrm{N}_{2}$ mixture $(20 / 20 / 60$; v/v/v, $130 \mathrm{kPa})$. Concentrations of substrates used in growth experiments were $20 \mathrm{mM}$ methanol, $5 \mathrm{mM}$ formate, $10 \mathrm{mM}$ acetate, $10 \mathrm{mM}$ sulfate, $10 \mathrm{mM}$ thiosulfate, 20 $\mathrm{mM}$ acetoin, $20 \mathrm{mM}$ 2,3-butanediol, $20 \mathrm{mM}$ propanol, $20 \mathrm{mM}$ ethanol, $20 \mathrm{mM}$ trimethylamine, and $20 \mathrm{mM}$ syringate.

\section{Sequencing strategy}

Genomic DNA of T. phaeum was isolated using the MasterPure $^{\mathrm{TM}}$ complete DNA purification kit (Epicentre, Madison, Wi., USA). The extracted DNA was used to generate 454 shotgun and paired-end libraries according to the manufacturer's protocols (Roche 454, Branford, USA). In each case, one quarter lane of a Titanium picotiter plate was used for sequencing of the libraries, resulting in 506605 total reads with 113390 paired reads. The reads were de novo assembled using the Roche Newbler assembly software 2.3 (Roche 454). Closure of remaining gaps and sequence polishing were done by PCR-based techniques and Sanger sequencing of PCR products using BigDye 3.0 chemistry and avn ABI3730XL capillary sequencer (Applied Biosystems, Life Technologies GmbH, Darmstadt, Germany). The Gap4 (v.4.11) software of the Staden package (Staden, 1998) was used for sequence editing. 


\section{Gene prediction and annotation}

Automatic gene prediction was performed with the YACOP and GLIMMER [35] software packages. All predicted genes were manually corrected based on GC frame plot analysis, the presence of ribosome-binding sites, and comparison to known protein-encoding sequences employing the Sanger Artemis tool v13 [36]. Functional annotation was initially carried out with the ERGO software suite [37] and the IMG/ER (Integrated Microbial Genomes/Expert Review) system [38]. Subsequently, the annotation was manually curated by comparison to the Swiss-Prot, TrEMBL, and InterPro database [39,40].

\section{Sequence analysis and comparative genomics}

Gene products were classified into functional categories performing a BLAST search against the COG database [41]. A bidirectional BLAST algorithm was used for comparative analyses of different organisms as described previously [42], combined with a global sequence alignment based on the Needleman-Wunsch algorithm [43]. Genes were assumed to be orthologs at a global alignment similarity of higher than $30 \%$ and a BLAST e-value lower than 10e-21. Visualization of the chromosome and other DNA sequences was done with DNAPlotter [44]. The pathway tool software from the BioCyc Database collection [45] was employed to analyze metabolic pathways. The reconstruction and validation of metabolic pathways was curated manually.

The multiple sequence alignment was perfomed with the ClustalW [46] and default settings were used. TAT motif prediction was performed with PRED-TAT [47].

\section{Assay of motility}

Motility was tested with two different methods. First, the motility of free-swimming cells was assayed under oxic conditions immediately after taking samples. Second, in order to force Th. phaeum to express potential flagella, swarm agar tubes were prepared [48]. Gelrite $(0.4 \%$, $0.6 \%$ and $1.0 \% \mathrm{w} / \mathrm{v}$ ) was used instead of agar, and 20 $\mathrm{mM}$ methanol was added as energy and carbon source.

\section{Detection of gas vesicles}

Gas vesicles were searched for by phase-contrast microscopy. For further investigation of light-diffracting structures inside the cells, a 1-ml culture was exposed to high pressure (150 bar) to destroy possible gas vesicles.

\section{Detection of phages}

A $50 \mathrm{ml}$ pure culture grown with $20 \mathrm{mM}$ methanol as substrate was centrifuged at $5,000 \times \mathrm{g}$ for $20 \mathrm{~min}$. The supernatant was transferred to a $50 \mathrm{ml}$ Falcon tube containing $1 / 6$ volume of a $20 \%(\mathrm{w} / \mathrm{v})$ PEG 6000 plus $2.5 \mathrm{M}$ $\mathrm{NaCl}$ solution, and precipitated overnight $(12 \mathrm{~h})$ at $4^{\circ} \mathrm{C}$. The mixture was centrifuged at 5,000 $\mathrm{x} g$ for $15 \mathrm{~min}$, and the pellet resuspended in $1 \mathrm{ml}$ TBS buffer $(50 \mathrm{mM}$ Tris-HCl, pH 7.4, supplemented with $150 \mathrm{mM} \mathrm{NaCl}$ ). After additional centrifugation at 13,000 $\mathrm{x} g$ for $5 \mathrm{~min}$, the supernatant was transferred to a new centrifuge tube and reprecipated with $1 / 6$ volume of $\mathrm{PEG} / \mathrm{NaCl}(20 \%$ $(w / v)$ PEG $6000+2.5 \mathrm{M} \mathrm{NaCl})$ for $1 \mathrm{~h}$ at $4^{\circ} \mathrm{C}$. The precipitated phages were recovered by centrifugation at $13,000 \times \mathrm{g}$ for $8 \mathrm{~min}$. The pellet was resuspended in $1 \mathrm{ml}$ TBS buffer (50 mM Tris-HCl, $\mathrm{pH}$ 7.4; supplemented with $150 \mathrm{mM} \mathrm{NaCl}$ ) and centrifuged again at 13,000 $\times g$ for $8 \mathrm{~min}$. The supernatant was stored at $4^{\circ} \mathrm{C}$ before further use.

Two different methods were used to detect active bacteriophages. A culture was concentrated to a final $\mathrm{OD}_{600}$ of 1.1 in a total volume of $10 \mathrm{ml}$ fresh medium containing $20 \mathrm{mM}$ methanol. One $\mathrm{ml}$ of the precipitated phage suspension described above or $1 \mathrm{ml}$ supernatant from a centrifuged outgrown culture $(8,000 \times g ; 10 \mathrm{~min})$ was added to the culture, and further growth was followed measuring $\mathrm{OD}_{600}$.

Primers were designed to amplify a specific major capsid protein (Tph_c23140) which was found in the genome (gep3034F: ACGCGGGAACGACGGACTG and gep3034R: CGGCGGGCGAACTCTTTG). The PCR reaction was performed as follows: $1 \times$ PCR buffer, $1.5 \mathrm{mM}$ $\mathrm{MgCl}_{2}, 0.1 \mathrm{mM}$ dNTPs, $1 \mathrm{U}$ Taq polymerase (all Invitrogen), $5 \mu \mathrm{M}$ of each primer, and sterile UV-irradiated water to give a final volume of $25 \mu \mathrm{l}$. One $\mu \mathrm{l}$ of extracted DNA of Clostridium pasteurianum or $1 \mu \mathrm{l}$ phage solution was added to two separate aliquots of this mixture and the reactions were heated to $94^{\circ} \mathrm{C}$ for $3 \mathrm{~min}$, followed by 30 cycles of $94^{\circ} \mathrm{C}$ for $60 \mathrm{~s}, 55^{\circ} \mathrm{C}$ for $50 \mathrm{~s}$ and $72^{\circ} \mathrm{C}$ for $90 \mathrm{~s}$. A final extension was carried out at $72^{\circ} \mathrm{C}$ for $10 \mathrm{~min}$. The $16 \mathrm{~S}$ rDNA gene was amplified to control whether the phage solutions were contaminated with genomic DNA. The following primers were used for 16S rDNA gene amplification 27f: GAGTTT GATCMTGGCTCAG and 1492R: GGTTACCTTGT TACGACTT. The PCR reaction was carried out as described above.

\section{Analysis of cytochromes}

Cell-free extract was prepared under oxic condition from a pure culture grown on methanol plus $\mathrm{CO}$, or formate. Redox difference spectra (dithionite-reduced minus air-oxidized) were recorded with a spectrophotometer (Uvikon 930, Kontron Instruments).

\section{Chemical analyses}

All substrates and products were analyzed by HPLC. Sulfate and thiosulfate were separated on an anion separation column (LCA A03, Sykam) with an eluent containing $5 \mathrm{mM} \mathrm{NaHCO}, 400 \mu \mathrm{M}$ 4-hydroxybenzonitril, and $10 \%(\mathrm{v} / \mathrm{v})$ acetonitril at $40^{\circ} \mathrm{C}$. Conductivity was 
measured with the S3115 conductivity detector (Sykam). Formate, methanol, and acetate were separated on an anion separation column (Aminex HPX-87H, Biorad) with a $5 \mathrm{mM}$ sulfuric acid eluent at $40^{\circ} \mathrm{C}$, and measured with a refraction detector (RID-10A, Shimadzu).

\section{Electron microscopy}

Cells were harvested by filtration through a $0.4 \mu \mathrm{m}$ PTFE Filter. The retentate was resuspended in $200 \mu \mathrm{l} 50$ $\mathrm{mM}$ Tris- $\mathrm{HCl}$ buffer, $\mathrm{pH} 8.0$, and fixed with $2.5 \%$ glutardialdehyde in $0.1 \mathrm{M} \mathrm{Na}$-Cacodylate. Ten $\mathrm{mM} \mathrm{CaCl}_{2}$ and $10 \mathrm{mM} \mathrm{MgCl} 2$ were added. Samples were filtered on a 1 $\mu \mathrm{m}$ PC membrane and washed with 30, 50, 70 and $90 \%$ ethanol. Afterwards, samples were dried by critical-point dehydration with carbon dioxide, followed by sputtering (Baltec SCD 10) with $5 \mathrm{~nm}$ gold-palladium. The Auriga cross-beam work station (Zeiss) was used for analysis.

\section{Results and discussion}

\section{General genome features}

The completed genome of Th. phaeum (accession number CP003732) comprises a single circular chromosome of 2,939,057 bp and an overall GC content of $53.88 \mathrm{~mol} \%$. Three complete rRNA clusters and 51 tRNA genes, including those for selenocystein incorporation, were identified in the genome. Approximately $75 \%$ of the open reading frames (ORFs) could be functionally annotated. The remaining 645 ORFs are made up of hypothetical proteins (631) or pseudogenes (14). 2165 (app. 73\%) of all predicted protein-encoding genes could be allocated to the 21 functional COGs (Cluster of Orthologous Groups). This is in the same range as described for other acetogenic bacteria such as Acetobacterium woodii WB1 and Moorella thermoacetica ATCC39073, or sulfate-reducing bacteria such as Desulfobacterium autotrophicum HRM2, Thermotoga lettingae TMO, and Desulfotomaculum kuznetsovii. Analysis of COG revealed that $\sim 34 \%$ of all protein-encoding genes fall into four main categories: amino acid transport and metabolism (10\%), replication, recombination and repair (9\%), energy metabolism (8\%), and coenzyme transport and metabolism (7\%).

Th. phaeum is a member of the order Thermoanaerobacterales within the very large and diverse phylum of the Firmicutes. A $16 \mathrm{~S}$ rRNA-based phylogenetic analysis (Figure 1) of all type strains of the order Thermoanaerobacterales revealed that Syntrophaceticus schinkii is the closest known relative of Th. phaeum. Like S. schinkii, Th. phaeum is known as a syntrophically acetateoxidizing bacterium able to oxidize acetate in coculture with a hydrogenotrophic methanogen. In contrast to the mesophilic S. schinkii which shows no significant growth above $40^{\circ} \mathrm{C}$, Th. phaeum is thermophilic with a growth optimum at $58^{\circ} \mathrm{C}$. Both bacteria also differ clearly in their substrate utilization patterns $[13,14]$.
Up to date, only 36 different genomes of this order are publicly available (NCBI Genbank and IMG databases). The overall $\mathrm{G}+\mathrm{C}$ content within this group varies between 34 and $59 \mathrm{~mol} \%$. With $54 \mathrm{~mol} \%$, Th. phaeum exhibits the third highest $\mathrm{G}+\mathrm{C}$ content; only $M$. thermoacetica ATCC 39073 and Ammonifex degensii KC4 have higher $\mathrm{G}+\mathrm{C}$ contents of 56 and 59 mol\%, respectively. Like Th. phaeum, both these bacteria were described to be thermophilic, with growth optima above $50^{\circ} \mathrm{C}$. The genomes of all Thermoanaerobacterales vary between 1.4 $\mathrm{Mb}$ and 3.3 Mb. With Coprothermobacter proteolyticus DSM 5265 being the smallest and Thermanaeromonas toyohensis ToBE DSM 14490 being the largest member of the class, $T$. phaeum matches very well with a size of $2.9 \mathrm{Mb}$. Phylogenetic analysis based on $16 \mathrm{~S}$ rRNA gene sequences revealed that the closest relatives of $T$. phaeum are members of the genera Caldanaerobius, Carboxydothermus, and Moorella. Comparison of all inferred proteins of $T$. phaeum with the proteins of all sequenced Thermoanaerobacterales is in good agreement with the phylogenetic relationship inferred by $16 \mathrm{~S}$ rDNA analysis. T. phaeum shows the highest number of orthologues (1516) to M. thermoacetica, another homoacetogenic organism.

\section{CRISPR defense system}

CRISPRs (Clustered Regularly Interspaced Short Palindromic Repeats) are widespread in many bacterial and almost all archaeal genomes [49]. The CRISPR/cas system is a prokaryotic defense mechanism and provides immunity against invading mobile genetic elements such as phages and plasmids in an RNA interference-like manner. CRISPR loci typically consist of different numbers of noncontiguous repeats with lengths ranging from 20 to $47 \mathrm{bp}$ [50] and unique spacers of different length and sequence between the repeats. Spacers arise from the integration of invader sequences that are integrated into CRISPS loci and act as immunity memory of past invasive elements [51]. CRISPR-associated sequence (cas) genes are often directly adjacent to the CRISPR loci.

In the genome of Th. phaeum, we identified two operons that encode Cas proteins. The first operon (Tphc24370-Tph_c24580) consists of genes encoding two metal-dependent nucleases (cas1 and cas2) that represent the universal core Cas genes, one RecB family exonuclease protein (cas4) and several proteins of the RAMP (repeat-associated mysterious proteins) superfamily. In addition, we identified a cas3' gene coding for an HD-nuclease and a cas $8 b$ gene coding for zinc-finger domain-containing proteins within the first operon. Cas3-type proteins are characteristic for all type I CRISPR-Cas systems, and the presence of cas $8 b$ within this operon allowed a further classification of this operon as the I-B/Tneap-Hmari subtype, according to the 


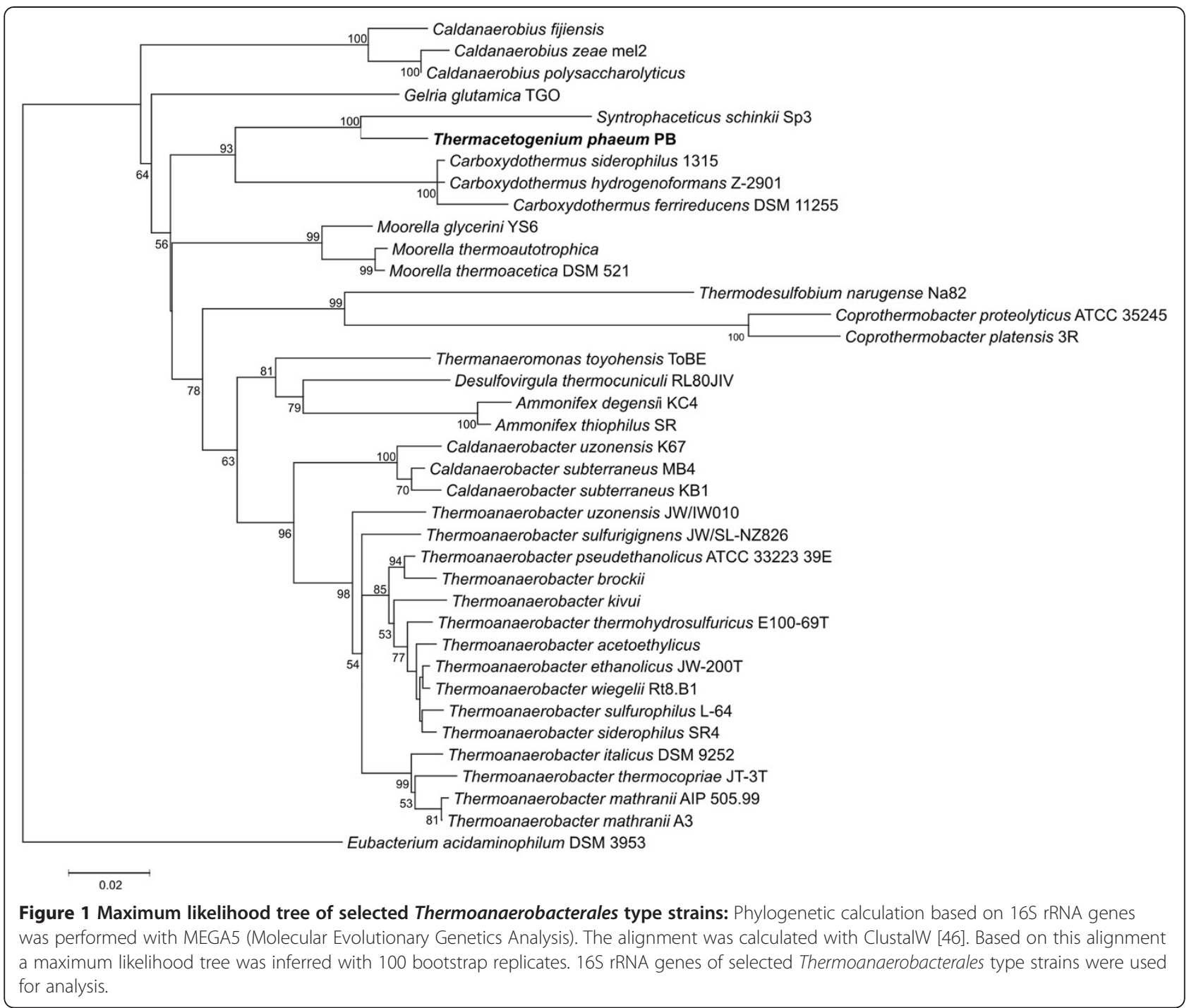

polythetic classification of CRISPR-Cas systems. The second operon (Tph_c18950-Tph_18980, Tph_c19070) also consists of cas 1, cas2, cas4, additionally a slightly distant located cas 6 and a gene coding for a Csa1 family protein. The composition of the operon allows to allocate it to the I-A/APERN subtype. However, the classification is uncertain as a type I CRISPR-Cas systemsspecific cas 3 is missing, as well as cas $8 a$, the signature gene that allows the classification as a I-A/APERN subtype [52].

In addition to the two mentioned cas operons, we detected 11 CRISPR loci in the genome of Th. phaeum. An analysis of 2091 completely sequenced prokaryotic genomes from the NCBI Genbank database (as of 201207-04) revealed that CRISPRs are present in about $87 \%$ of archaeal genomes (105 genomes), but only in $55 \%$ of bacterial genomes (980 genomes). In all CRISPRcontaining organisms the number of CRISPR loci varies between one and 21. One third of organisms contain one locus and approximately $75 \%$ harbor between one and three CRISPR loci. A small group of 28 prokaryotic organisms ( 4\%), including Th. phaeum, contain ten or more CRISPR loci. To date, Arthrospira platensis strain NIES 39 contains the highest number of different CRISPR loci (21). An analysis of the isolation sites and habitats of the aforementioned 28 species revealed that the majority are either thermophiles (e.g. Th. phaeum), hyperthermophiles, acidophiles, or halophiles (except for six species). These results may indicate that especially organisms living in extreme habitats very often have to cope with mobile genetic elements and the resulting horizontal gene transfer. Extreme habitats may require horizontal gene transfer and its regulation to adapt to fast environmental changes. As described above, we could identify 11 CRISPR arrays in the genome of $T h$. phaeum. The number of direct repeats within the arrays 
varies between eight in the smallest loci and 105 and 113 in the two largest loci. Compared to other CRISPRcontaining organisms, the extreme range of direct repeats is unusual. Our analysis discovered that only 9.3\% of all organisms sequenced so far contain CRISPR arrays with more than 100 repeats.

\section{Substrate tests and pathway construction}

The information obtained from the sequenced and annotated genome on substrate degradation was counterchecked with growth experiments with Th. phaeum and compared with results of previous growth experiments. In addition to prior known growth substrates, we also observed growth with carbon monoxide. It was previously shown that $T h$. phaeum can grow independent of sodium ions in sodium-free media with pyruvate as substrate [53]. This was confirmed with other growth substrates (CO, formate, methanol), down to a limit of about $100 \mu \mathrm{M} \mathrm{Na}^{+}$. Th. phaeum grew with methanol, acetoin, 2,3-butanediol, and ethanol in pure culture; and in syntrophic co-culture with acetoin and, rather weakly, with 2,3-butanediol and ethanol (Table 1). No growth was observed with syringate and trimethylamine.

\section{Sulfur metabolism}

Cysteine is the primary source of sulfur for Th. phaeum, and is required especially for $\mathrm{Fe}-\mathrm{S}$ cluster formation. There are three different $L$-cysteine degradation pathways known which all form pyruvate as an intermediate, but none of the key enzymes ( $L$-cysteine:oxygen oxidoreductase, $L$-cysteine desulfhydrase, $L$-cysteine aminotransferase) was found in the genome of Th. phaeum. We identified four different cysteine desulfurase genes (Tph_c09490, Tph_c17300, Tph_c17960, Tph_c19200). One of them is located in a nif-like operon which is probably involved in the formation of the Fe-S cluster of nitrogenase. The other three genes are dispersed in the genome, and the gene neighbourhood shares no similarity to other well-known operons involved in Fe-S cluster assembly, such as the suf or the isc operon $[54,55]$.

According to its original description, Th. phaeum can reduce sulfate, but we could not reproduce this result. Weak growth with acetate plus sulfate was observed (an OD rise from 0.04 to 0.08 ) but never increased further, even after several months of incubation or substrate addition. Measurement of sulfate with $\mathrm{BaCl}_{2}$ solution or HPLC analysis revealed that the sulfate concentration did not decrease. The only hint towards sulfate metabolism in the genome was a sulfate permease (Tph_c27320), but key enzymes of sulfate reduction such as sulfate adenyltransferase or APS reductase were not found. Interestingly, there were two thiosulfate reductase genes (Tph_c01240, Tph_c01280), but growth with thiosulfate could not be observed, and genes necessary for sulfite reduction were not found either.

\section{Cofactors and vitamins}

Tetrahydrofolate is the most important cofactor in the Wood-Ljungdahl pathway. A closer look at the pathway of tetrahydrofolate biosynthesis revealed that all required genes despite one were present. The dihydrofolate reductase gene is missing in the genome. BLASTP searches with known sequences of dihydrofolate reductases against the Th. phaeum genome revealed no proper candidate for such an enzyme. However, it was shown that a dihydropteridine reductase [EC 1.5.1.34] of Thermus thermophilus showed $20 \%$ activity with dihydrofolate as substrate [56]. The metabolic role of dihydrobiopterine is not well understood; some aromatic amino acid hydroxylases use tetrahydrobiopterine as reducing agent while dihydrobiopterine is regenerated by dihydropteridine reductase [57]. Thus, it is likely that the product of this gene (Tph_c13060) which shows similarities to that of dihydropteridine reductase fulfills the role of the dihydrofolate reductase in Th. phaeum.

Table 1 Growth of Thermacetogenium phaeum with different substrates in pure and syntrophic co-culture

\begin{tabular}{|c|c|c|c|c|c|c|}
\hline Pure culture & $\Delta O D_{600}$ & $\begin{array}{l}\text { Cell density } \\
{\left[\left.\mathrm{mg} \cdot\right|^{-1}\right]}\end{array}$ & $\begin{array}{l}\text { Substrate utilized } \\
{[\mathrm{mM}]}\end{array}$ & $\begin{array}{l}\text { Acetate formed } \\
{[\mathrm{mM}]}\end{array}$ & $\begin{array}{l}\text { electron } \\
\text { balance [\%] }\end{array}$ & $\begin{array}{l}\text { Molar growth yield } \\
Y_{E}\left[\mathrm{~g} \cdot \mathrm{mol}^{-1}\right]\end{array}$ \\
\hline Acetoin & 0.05 & 12.5 & 7.3 & 10.5 & 97.5 & 1.71 \\
\hline 2,3 Butanediol & 0.046 & 11.5 & 4.5 & 8.3 & 151.3 & 2.56 \\
\hline Methanol & 0.583 & 145.8 & 12.2 & 7 & 86.5 & 11.95 \\
\hline Ethanol & 0.047 & 11.75 & 15.3 & 17.2 & 75.5 & 0.77 \\
\hline \multicolumn{7}{|c|}{ Syntrophic culture } \\
\hline Acetoin & 0.377 & 94.25 & 7.4 & 12.5 & 128.5 & 12.74 \\
\hline 2,3 Butanediol & 0.045 & 11.25 & 7.7 & 11.4 & 120.1 & 1.46 \\
\hline Methanol & 0.02 & 5 & 0.2 & 0.2 & - & - \\
\hline Ethanol & 0.07 & 17.5 & 20.2 & 15.7 & 52.3 & 0.87 \\
\hline
\end{tabular}

Molar growth yields $(\mathrm{Y})$ and electron balance were calculated using the formula $\left\langle\mathrm{C}_{4} \mathrm{H}_{7} \mathrm{O}_{3}\right\rangle$ for cell material and the experimentally determined conversion factor OD600 $=1=0.250 \mathrm{~g}$ cell mass. $\mathrm{L}^{-1}$.

Data show growth after 4 weeks. In most cases no further growth could be observed. 
Also cobalamin is a necessary cofactor in the WoodLjungdahl pathway, and is involved in the activation of several methylated compounds as well. The synthesis pathway could not be fully reassembled because several enzymes are missing. Starting with $L$-glutamate, all genes for the synthesis of precorrin-2 were found. Of the two pathways for cobalt insertion, i. e., the "early" and the "late" cobalt insertion pathway [58,59], two enzymes are missing in either case. The "early" cobalt insertion path lacks putative genes encoding the precorrin-2 cobalt chelatase and the cobalt-precorrin-7 (C15)-methyltransferase genes, while the "late" one has no putative precorrin-3B synthase and precorrin-6B synthase encoding genes. Since the "late" cobalt insertion pathway requires oxygen, only the "early" cobalt insertion pathway is likely to operate in Th. phaeum. Most genes for this pathway are located in one operon, but possible genes for missing enzymatic reactions are dispersed in the genome such as a cobalt insertion protein (Tph_c03440) which is similar to cobN. This gene is found in the "late" cobalt insertion pathway which forms a heterotrimeric cobalt chelatase complex CobNST [60], but there is no indication of cobS- or cobT-like genes in the genome. Other chelatases might substitute for this function by similar reactions which are not directly linked to a cobalt chelatase, e. g., Mg chelatase (Tph_c17340, Tph_c17350, Tph_c10400) or cysG (Tph_c15350). CysG is a bifunctional methyltransferase and ferrochelatase which is involved in siroheme synthesis. This enzyme can also be involved in cobalamin synthesis [61] and may act in cobalt insertion [62].

Possible biosynthesis of quinones would be of interest because quinones could be involved in electron transport and proton translocation. It was reported earlier that Th. phaeum contains menaquinone-7 [13]. All genes necessary for menaquinone biosynthesis were found except for the 1,4-dihydroxy-2-naphthoate octaprenyltransferase. Only one candidate gene coding for an ubiA prenyltransferase-like (Tph_c02040) enzyme was found which shares no sequence similarities to known 1,4-dihydroxy-2-naphthoate octaprenyltransferase genes. Thus, it is questionable whether this gene is the missing link, but the presence of a menaquinone-7 has been proven in earlier studies [13].

No genes were found that could be involved in cytochrome biosynthesis. We also looked for the presence of cytochromes via redox difference spectral analysis after growth under different conditions but could not find any absorbance bands typical of cytochromes.

\section{$\mathrm{CO}_{2}$ fixation and wood-ljungdahl pathway}

Previous experiments had shown that Th. phaeum reduces $\mathrm{CO}_{2}$ to acetate through the Wood-Ljungdahl pathway [63]. We found all genes necessary for this pathway in the genome, and most of them were encoded only once.
However, there were four different gene clusters for formate dehydrogenases, three for carbon monoxide dehydrogenases, and two for formyl tetrahydrofolate synthetase genes. One formate dehydrogenase gene (Tph_c26260) is located inside a putative formate hydrogen lyase operon, with four possibly membrane-associated hydrogenase subunits. The genes for the other three formate dehydrogenases were found dispersed in the genome, but one of them (Tph_c15380- Tph_c15400) has three subunits (alpha, beta and gamma) and is located close to a siroheme biosynthesis operon. Interestingly, the gamma subunit (Tph_c15380) shares similarity with a cytochrome $b_{561}$ subunit, and is very likely to be membrane-associated. None of these formate dehydrogenase has a TAT motif, thus they are not periplasmic. One of the carbon monoxide dehydrogenases is the bifunctional carbon monoxide dehydrogenase/acetyl-CoA synthase (Tph_c15170, Tph_c15180), the key enzyme of the Wood-Ljungdahl pathway. It is located in the acs operon which contains in addition a methyltetrahydrofolate:corrinoid/iron-sulfur methyltransferase (Tph_c15130), a corrinoid/iron-sulfur protein (Tph_c15140), and the methylenetetrahydrofolate reductase (Tph_c15100). An interesting feature of the acs operon is the presence of two genes resembling heterodisulfide reductase genes (Tph_c15090, Tph_c15120). There are two further carbon monoxide dehydrogenase genes (Tph_c05730, Tph_c11250) which are similar to the proton-translocating carbon monoxide dehydrogenase of Methanosarcina barkeri.

The genomes of three other homoacetogenic bacteria have been sequenced and annotated, i. e., A. woodii [28], M. thermoacetica [27,28], and Clostridium ljungdahlii [30].

A. woodii has no cytochromes or menaquinone, but uses an Rnf complex to establish a sodium ion gradient across the membrane [64]. During growth of $A$. woodii with $\mathrm{H}_{2}$ plus $\mathrm{CO}_{2}$, an electron-bifurcating [FeFe]-hydrogenase uses $6 \mathrm{~mol} \mathrm{H}_{2}$ to reduce $3 \mathrm{~mol} \mathrm{NADH}$ and $3 \mathrm{~mol}$ ferredoxin. Ferredoxin is reoxidised by the $\mathrm{Rnf}$ complex to reduce another $3 \mathrm{~mol} \mathrm{NAD}{ }^{+}$and translocate six mol of $\mathrm{Na}^{+}$. The NADH is channelled into the methylene-THF dehydrogenase and methylene-THF reductase, and the latter reaction is supposed to reduce ferredoxin by a bifurcation reaction which is used further to reduce $\mathrm{CO}_{2}$ to $\mathrm{CO}$. An enzyme complex composed of a FeFe hydrogenase, an iron-sulfur protein and a molybdenum/tungsten-dependent formate dehydrogenase catalyzes the reduction of another $\mathrm{CO}_{2}$ to formate [28]. This type of homoacetogenic metabolism requires a bifurcating hydrogenase [65], a sodiumpumping Rnf complex and a bifurcating methylene-THF reductase/ferredoxin reductase to conserve a fraction of an ATP equivalent per reaction with the help of a sodiumpumping ATPase.

Energy conservation during lithotrophic growth of Moorella thermoacetica is less clear. Current evidence 
suggests that energy is conserved in the corrinoiddependent transmethylation from methyl-THF to the acetyl-CoA synthase enzyme. Further energy has to be obtained in electron transport via menaquinone, FAD or cytochrome to methylenetetrahydrofolate (methyleneTHF) [66] $\left(\mathrm{E}_{0}=-200 \mathrm{mV}\right.$ [67]). M. thermoacetica also contains a bifurcating hydrogenase [68]. In contrast to A. woodii [28], M. thermoacetica [50] is not sodiumdependent but probably fuels its ATP synthesis through proton translocation.

Also C. ljungdahlii is sodium ion-independent but does not contain cytochromes. In this bacterium, a proton-pumping Rnf complex appears to play a major role in energy conservation [30].

Based on these results, it appears that Th. phaeum differs from the two other metabolic types of homoacetogenic bacteria characterized above, the proton-dependent cytochrome-containing $M$. thermoacetica and the sodiumdependent $A$. woodii. In Th. phaeum there is no Rnf complex; only one gene (Tph_c26790) shares weak similarity to RnfC. However, Th. phaeum contains four genes (Tph_c18430 - Tph_c18460) which may compose a potentially bifurcating [FeFe]-hydrogenase, similar to the [FeFe]-hydrogenase of $A$. woodii [28] or Thermotoga maritima $[69,70]$ (Figure 2). These genes, which have been annotated as NADH:quinone oxidoreductase, share high similarities; hence, it is tempting to predict a bifurcating hydrogenase in Th. phaeum which can connect to methylene-THF reduction or oxidation, either directly or indirectly via a menaquinone. Next to the putative hydrogenase, a formate dehydrogenase subunit (Tph_c18420) is located, suggesting a potential link between formate oxidation und bifurcating hydrogen formation.

In addition, four further putative hydrogenases were found in the genome. One shares similarity to a non- $\mathrm{F}_{420}$ reducing hydrogenase (Tph_c26910), one is similar to an Ech hydrogenase (Tph_c21310- Tph_c21360), one is connected to a formate hydrogen lyase system (Tph_c26250Tph_c26370), and the last one is a periplasmic [NiFeSe] hydrogenase (Tph_c06350, Tph_c06360, Tph_c06370). The Ech hydrogenase and the formate hydrogen lyase are of special interest because they both could couple to proton translocation and interestingly are also found in Moorella thermoacetica [71,72].

Carbon monoxide dehydrogenases can use different electron acceptors such as ferredoxin or rubredoxin [73-75]. Some of these are involved in proton translocation [76]. Th. phaeum has three carbon monoxide dehydrogenases. One is the bifunctional carbon monoxide dehydrogenase/acetylCoA synthase (Tph_c15170, Tph_c15180). The other two (Tph_c05730, Tph_c11250) consist of two subunits each and are both similar to the proton-translocating carbon monoxide dehydrogenase of $M$. barkeri [76]).

Despite that, a further energetic problem has to be considered. The oxidation of methyl-THF to methyleneTHF with $\mathrm{NAD}^{+}$as electron acceptor is an endergonic reaction. Methylene-THF reductase (Tph_c15100) is found only once in the genome and is located in the acs gene cluster; a heterodisulfide reductase-homologous gene is found nearby. It was proposed that these genes and a hydrogenase could form a complex which is likely involved in proton translocation [77], but this is possible only if methylene-THF is reduced to methyl-THF. In the endergonic, oxidative direction, a proton gradient could provide the necessary energy, e. g. established through an Rnf complex.

\section{ATP synthase}

A $F_{1} F_{0}$-type ATP synthase was found in the genome which consists of 7 subunits. The gamma subunit of the

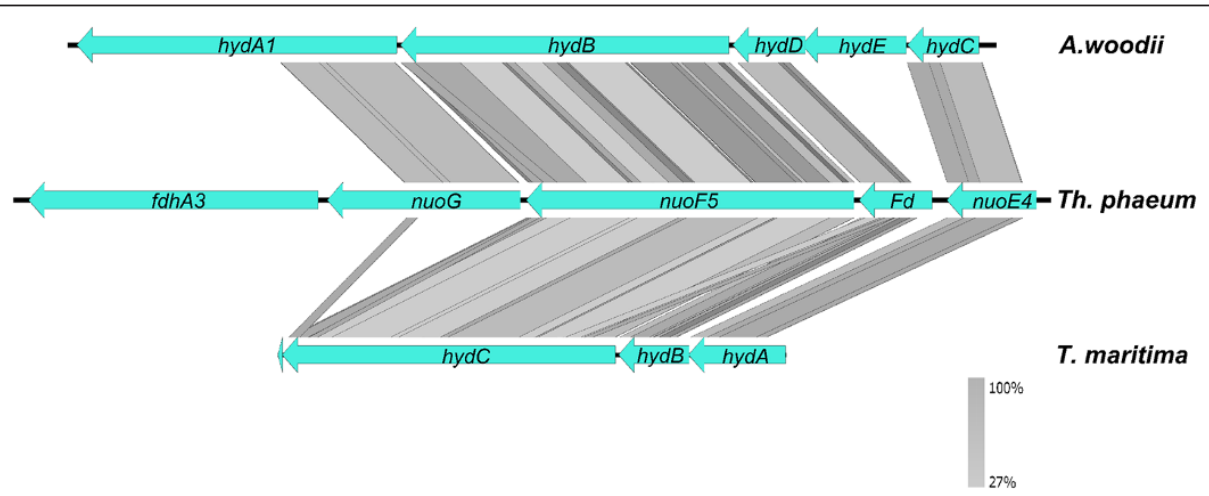

Figure 2 Comparison of the putative bifurcating hydrogenase gene clusters of Th. phaeum with Acetobacterium woodii and Thermotoga maritima. Linear comparison of the bifurcating hydrogenase gene loci from A. woodii and T. maritima with Th. phaeum was perfomed with tBlastx using easyfig [83]. The lines indicate sequence identity ranging from $27 \%$ light grey to $100 \%$ dark grey. It shows that nuoG, nuoF5, Fd (ferredoxin-like) und nuoE4 are similar to the bifurcating hydrogenases of T. maritima and A. woodii. For each gene, several paralogue genes are found in the Th. phaeum genome; two further gene clusters are likely containing putative hydA, hydB and hydC genes (Tph_C14870Tph_c14890 and Tph_c08240-Tph_c08260). 
$\mathrm{F}_{0}$-complex is involved in the proton- or sodiumpumping activity. Sequence alignments show that the gamma subunit (Tph_c27380) of T. phaeum shares some similarities with proton-dependent ATP synthase but also with sodium-dependent ATP synthase (Figure 3). The sodium binding motif differs slightly from other $\mathrm{c}$ subunit of known sodium-dependent anaerobes, but has the same motif as the proton-dependent cyanobactierum Synechococcus elongatus. This might explain why sodium ions at different concentrations did not impact on growth, and might indicate that the T. phaeum ATP synthase is proton-dependent as well.

\section{Flagella, gas vesicles, and bacteriophages}

Thermacetogenium phaeum was reported to be a motile bacterium. The genome contains a complete set of flagellum genes. While the type III secretion system genes, motor/switch, basal body, and hook-associated genes are located on one operon (Tph_c10790 - Tph_c11040), the other genes involved in flagellum assembly, i. e. the filament (Tph_c22150), hook-filament junction (Tph_c05670, Tph_c05690), and filament cap gene (Tph_c22170), were found dispersed in the genome. The $\mathrm{L}$ and $\mathrm{P}$ ring genes and several transcriptional regulators were missing. Motility could explain how Th. phaeum and the methanogenic partner can get into close contact in order to establish an efficient syntrophic cooperation. Flagella were found by electron microscopy of young cells in syntrophic culture (Figure 4A). However, in swarm agar tubes [48] synthesis of flagella could not be induced. Additionally, a long, rod-shaped structure of 5-10 nm width and several micrometers length was found in the supernatant of syntrophic cultures which was never found in pure cultures grown with carbon monoxide.Th. phaeum might express a flagellum at an early stage of growth to establish close contact to a suitable partner organism. Because of their extreme energy limitation, the cells may loose the flagellum afterwards due to the high energy consumption associated with the maintenance and use of a flagellum.

The genome contains ten genes for synthesis of gas vesicles, which are located on one operon (Tph_c10500 -
Tph_c10640). Four genes code for different sizes of the structural protein GvpA, which forms the main mass of the gas vesicle structure. Another structural protein GvpC was identified which enforces gas vesicle. Two types of the $g v p L / g v p F$ genes and one copy of $g \nu p G, g \nu p K, g v p N$ each were detected; all these genes are likely to be involved in the formation of the gas vesicle [78]. Thus, gas vesicle formation in Th. phaeum is genetically possible, but they were never detected in growing cultures. Additionally, floating cells could not be observed either.

Another interesting feature is a set of genes (Additional file 1: Table S1) that comprise a complete bacteriophage genome. Earlier experiments had indicated that the culture may harbor a phage: During growth of five replicate cultures, always one or two cultures grew slower than the other ones although the growth conditions were exactly identical. Possible phages were concentrated by PEG/NaCl precipitation from the supernatant of such cultures, and this phage preparation was added to a dense culture at OD 1.0. While the control culture continued to grow up to OD 1.2 the culture with the phage suspension showed no growth at all. Since the phage-related genes were known, a primer pair targeting specific phage DNA was designed. PCR was employed to show that the supernatant contained phage DNA (Figure 5) which might be a result of active phages. In order to check whether the supernatant contain genomic DNA primer for $16 \mathrm{~S}$ rDNA were used. No bands were visible which means that the band from the phage specific primer results from an active phage and not a prophage. The band in the Clostridium pasteurianum lane $(\mathrm{Ph})$ may be an uspecific product, because no similar gene was found in the C. pasteurianum genome.

To confirm these results, we performed electron microscopy and found regularly shaped round structures, which might be phages (Figure 4B). Obviously, this phage impairs growth of Th. phaeum in pure and syntrophic culture. Unfortunately, we could not identify the trigger which activates the lytic cycle. So far, the phage appears to impair growth randomly under different growth conditions with different substrates. After severe lysis, cultures were able to recover and to resume 


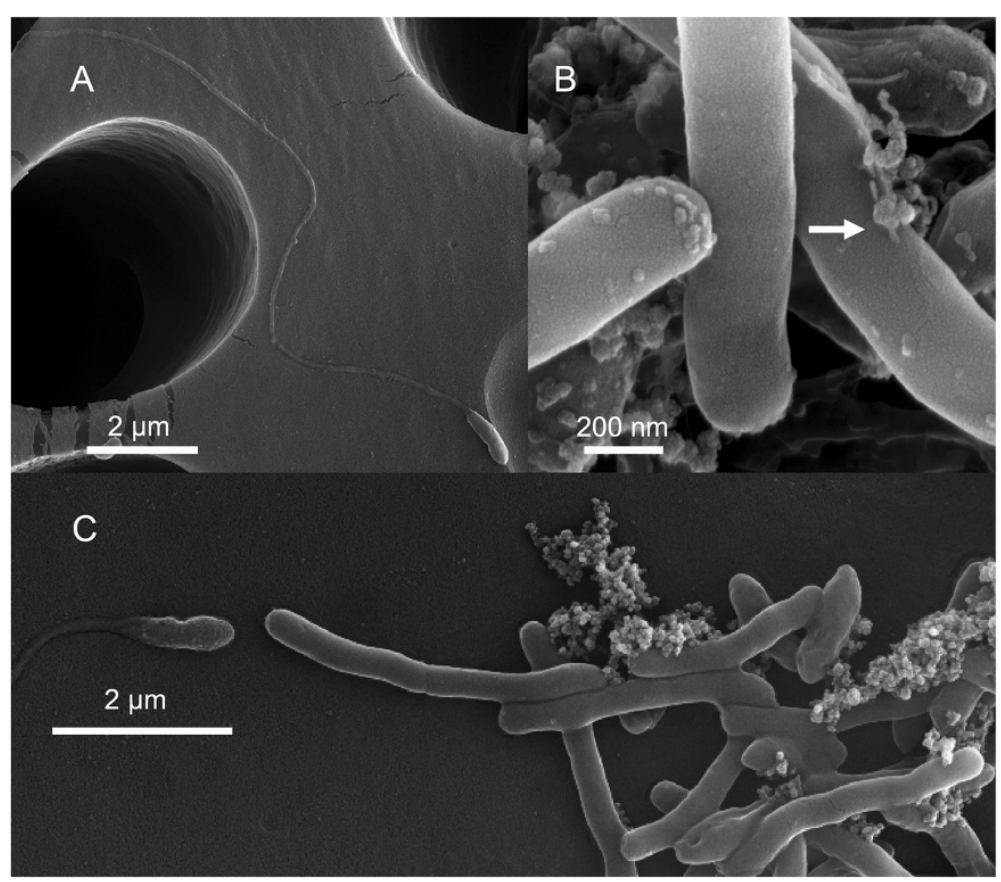

Figure 4 Electron micrographs of a syntrophically grown co-culture of Th. Phaeum and Methanothermobacter thermautotrophicus strain TM. A Young cell with flagellum. B Round structures on top of cells that might comprise bacteriophages; some show a tail-like structure (arrow). C Outgrown cells forming aggregates do not carry flagella.

growth again. The phage might be the reason for extremely low growth yields, especially during growth with "difficult" substrates such as $\mathrm{CO}, \mathrm{H}_{2}$, or formate.

\section{Energy conservation during growth in pure culture}

Two ways of methanol oxidation are possible. It was reported that in Clostridium thermoautotrophicum the oxidation of methanol via formaldehyde to formate involves a pyrroloquinoline quinone-dependent methanol dehydrogenase [79]. Other methylotrophic homoacetogens transfer the methyl group to a different methyl acceptor, which is either a corrinoid Fe-S protein or tetrahydrofolate [80,81]. Th. phaeum uses the second pathway, because a methanolcobalamin methyltransferase (Tph_c03590) was found which likely activates and transfers the methyl group to a methyl acceptor. The genome contained several alcohol dehydrogenases, but a dehydrogenase activity with methanol could not be found. Fermentation of 4 mol methanol yields 3 mol acetate:

4. Methanol $+2 \mathrm{CO}_{2} \rightarrow 3$ Acetate $^{-}+3 \mathrm{H}^{+}+2 \mathrm{H}_{2} \mathrm{O}$ $\Delta \mathrm{G}^{0^{\prime}}=-52.3 \mathrm{~kJ}$ per mol methanol [82].

This fermentation yields one ATP equivalents for the oxidation of one methanol and yields three ATP in the acetate kinase reaction. Part of this ATP surplus has to be sacrificed to drive the endergonic oxidation of methyl-THF to methylene-THF (see above). To our surprise, no growth with methanol was observed in the syntrophic co-culture.

Growth with $\mathrm{CO}$ is energetically easy:

4. $\mathrm{CO}+2 \mathrm{H}_{2} \mathrm{O} \rightarrow$ Acetate $^{-}+\mathrm{H}^{+}+2 \mathrm{CO}_{2} \Delta \mathrm{G}^{0^{`}}=-175.0$ kJ per mol.

Due to the low redox potential of the $\mathrm{CO}_{2} / \mathrm{CO}$ couple $\left(E^{\circ}=-520 \mathrm{mV}\right), \mathrm{CO}$ oxidation can deliver electrons to all reduction steps in the Wood-Ljungdahl pathway, and net ATP formation could be fueled through protontranslocating $\mathrm{CO}$ dehydrogenases for which evidence was obtained in the genome. Nonetheless, growth of $T h$. phaeum with $\mathrm{CO}$ was often difficult to reproduce; perhaps the bacteriophage that we found in the genome is activated especially in the presence of this low-potential electron donor.

Growth experiments confirmed growth with acetoin, but growth with ethanol and 2,3-butanediol was rather poor. Methanol was used only in pure culture. No growth was observed with syringate or trimethylamine (Table 1).

According to the genomic data, 2,3-butanediol is degraded via acetoin and further cleaved to acetaldehyde plus acetyl-CoA, with $\mathrm{NAD}^{+}$as electron acceptor. Acetaldehyde can be oxidized to acetate, either by an acetylating 


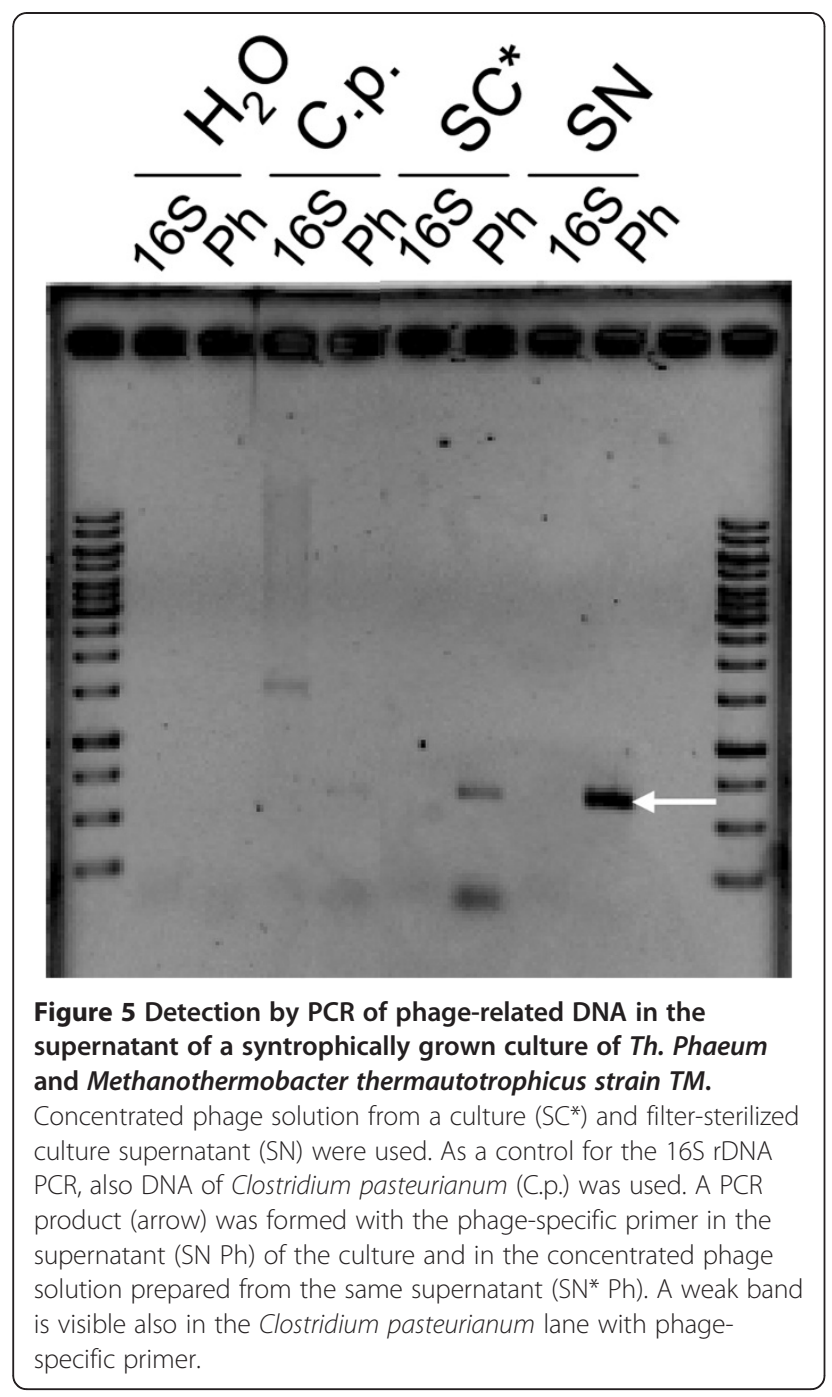

aldehyde dehydrogenase, phosphate acetyltransferase and acetate kinase, or be oxidized by a non-acetylating acetaldehyde dehydrogenase directly to acetate. In the first pathway, a total of 2 ATP and $2 \mathrm{NADH}$ is formed. The only $\mathrm{NADH}$-dependent hydrogenase found in the genome is the putatively bifurcating [Fe]-hydrogenase. The other pathway forms one NADH, one reduced ferredoxin, and ATP. This pathway might be more likely because the reduced ferredoxin is already available. Comparing growth of the syntrophic co-culture and the pure culture with acetoin, it appears that hydrogen formation is the energylimiting step. Substrate utilization and product formation in both growth modes are similar, but the syntrophic culture reaches a far higher OD. Interestingly, there is no difference between the pure and the syntrophic culture during growth on 2,3-butanediol, indicating that in this case the methanogen does not help by syntrophic electron removal. The same applies to oxidation of ethanol to acetate: we found nearly quantitative substrate conversion but only very weak growth. So far, we have no explanation for this observation.

It was also reported that Th. phaeum grew with syringate or vanillate. Several o-methyltransferase-like proteins (Tph_c05610, Tph_c22260) and tri-/dimethylamine methyltransferases (Tph_c27660- Tph_c27720, Tph_c05860, Tph_c05880) were found in the genome which may transfer the methyl group of the corresponding substrate to tetrahydrofolate and ferment it analogous to methanol. However, no growth was observed on syringate or trimethylamine either.

\section{Syntrophic growth with acetate}

Th. phaeum degrades acetate syntrophically and forms $\mathrm{H}_{2}$ and $\mathrm{CO}_{2}$ (and possibly formate) which can be used further by the methanogenic partner to form methane.

$\mathrm{CH}_{3} \mathrm{COO}^{-}+\mathrm{H}^{+}+2 \mathrm{H}_{2} \mathrm{O} \rightarrow 2 \mathrm{CO}_{2}+4 \mathrm{H}_{2} \Delta \mathrm{G}^{0^{\prime}}=+95$ kJ per mol rct.4 $\mathrm{H}_{2}+\mathrm{CO}_{2} \rightarrow \mathrm{CH}_{4}+2 \mathrm{H}_{2} \mathrm{O} \Delta \mathrm{G}^{0^{\prime}}=$ $-131 \mathrm{~kJ}$ per mol rct. $\mathrm{CH}_{3} \mathrm{COO}^{-}+\mathrm{H}^{+}+\rightarrow \mathrm{CH}_{4}+\mathrm{CO}_{2}$ $\Delta \mathrm{G}^{0^{\prime}}=-35 \mathrm{~kJ}$ per mol rct.

The final acceptor for the released electrons is $\mathrm{H}^{+}\left(\mathrm{E}_{0}=\right.$ $-300 \mathrm{mV}$ [15], $\mathrm{pH}$ 7.0, $10 \mathrm{~Pa} \mathrm{H}_{2}$ ) at a redox potential lower than the methylenetetrahydrofolate/methyltetrahydrofolate couple. Th. phaeum uses the Wood-Ljungdahl pathway for $\mathrm{CO}_{2}$ fixation and acetate oxidation. An interesting question is whether the same enzymes are involved under both growth conditions. Besides formate dehydrogenase, $\mathrm{CO}$ dehydrogenase, and hydrogenase, only the formyl-THF synthetase has a further paralogue gene in the genome (Tph_c08280, Tph_c26780). As discussed above, formate dehydrogenase, $\mathrm{CO}$ dehydrogenase, methyleneTHF reductase and hydrogenase are of special interest concerning the energy conservation in both directions.

Based on our data it is likely that different enzymes are expressed under different growth conditions to allow ATP synthesis in either direction. Only methylene-THF reductase is present only once. The different pathways of energy conservation will be subject to further studies in our lab.

\section{Additional file}

Additional file 1: Table S1. List of putative prophage genes.

\section{Competing interests}

The author declares there are no competing interests.

\section{Authors' contribution}

DO, AP, AL and NM did most of the gene annotations, RD and GG contributed further to gene annotations, AP did the genome sequencing, DO provided the experimental data, A.P. and D.O. prepared the figures, and DO, AP and BS wrote the manuscript. All authors read and approved the final manuscript. 


\section{Acknowledgement}

The authors want to thank Satoshi Hattori and Yoichi Kamagata for suppor and valuable discussions. Antje Wiese helped with media preparations and growth experiments and Kathleen Gollow helped with technical support. Financial support by the Deutsche Forschungsgemeinschaft, Bonn-Bad Godesberg, Germany, is greatly acknowledged.

\section{Author details}

'Department of Biology, Microbial Ecology, University of Konstanz, Konstanz D-78457, Germany. ${ }^{2}$ Genomic and Applied Microbiology and Göttingen Genomics Laboratory, Georg-August University Göttingen, Göttingen, D-37077, Germany. ${ }^{3}$ Department of Microbiology and Institute for Genomic Biology, University of Illinois, 601 S. Goodwin, Urbana, IL 61801, USA.

Received: 23 October 2012 Accepted: 19 December 2012 Published: 23 December 2012

\section{References}

1. Mountfort DO, Asher RA: Changes in proportions of acetate and carbon dioxide used as methane precursors during the anaerobic digestion of bovine waste. Appl Environ Microbiol 1978, 35(4):648-654

2. Lovley $D R$, Klug MJ: Intermediary metabolism of organic matter in the sediments of a eutrophic lake. App/ Environ Microbiol 1982, 43(3):552-560

3. Rothfuss F, Conrad R: Thermodynamics of methanogenic intermediary metabolism in littoral sediment of Lake Constance. FEMS Microbiol Ecol 1993, 12(4):265-276.

4. Conrad R: Contribution of hydrogen to methane production and control of hydrogen concentrations in methanogenic soils and sediments. FEMS Microbiol Ecol 1999, 28(3):193-202

5. Conrad R: Quantification of methanogenic pathways using stable carbon isotopic signatures: a review and a proposal. Org Geochem 2005, 36 (5):739-752

6. Zehnder AJB, Ingvorsen K, Marti T: Microbiology of methane bacteria. Elsevier Biomedical press BV 1982, 22:45

7. Jetten MSM, Stams AJM, Zehnder AJB: Methanogenesis from acetate: a comparison of the acetate metabolism in Methanothrix soehngenii and Methanosarcina spp. FEMS Microbiol Lett 1992, 88(3-4):181-197.

8. Karakashev D, Batstone DJ, Trably E, Angelidaki I: Acetate oxidation is the dominant methanogenic pathway from acetate in the absence of Methanosaetaceae. Appl Environ Microbiol 2006, 72(7):5138-5141.

9. Zinder $\mathrm{SH}$, Koch M: Non-aceticlastic methanogenesis from acetate: acetate oxidation by a thermophilic syntrophic coculture. Arch Microbiol 1984, 138(3):263-272

10. Nusslein B, Chin KJ, Eckert W, Conrad R: Evidence for anaerobic syntrophic acetate oxidation during methane production in the profundal sediment of subtropical Lake Kinneret (Israel). Environ Microbiol 2001, 3(7):460-470.

11. Rui J, Qiu Q, Lu Y: Syntrophic acetate oxidation under thermophilic methanogenic condition in Chinese paddy field soil. FEMS Microbiol Ecol 2011, 77(2):264-273

12. Schnurer A, Schink B, Svensson BH: Clostridium ultunense sp. nov., a mesophilic bacterium oxidizing acetate in syntrophic association with a hydrogenotrophic methanogenic bacterium. Int J Syst Bacteriol 1996, 46 (4):1145-1152.

13. Hattori S, Kamagata $Y$, Hanada S, Shoun H: Thermacetogenium phaeum gen. nov., sp. nov., a strictly anaerobic, thermophilic, syntrophic acetateoxidizing bacterium. Int J Syst Evol Microbiol 2000, 50 Pt 4:1601-1609.

14. Westerholm M, Roos S, Schnurer A: Syntrophaceticus schinkii gen. nov., sp. nov., an anaerobic, syntrophic acetate-oxidizing bacterium isolated from a mesophilic anaerobic filter. FEMS Microbiol Lett 2010, 309(1):100-104.

15. Schink B: Energetics of syntrophic cooperation in methanogenic degradation. Microbiology and molecular biology reviews: MMBR 1997, 61(2):262-280.

16. Shigematsu T, Tang Y, Kobayashi T, Kawaguchi H, Morimura S, Kida K: Effect of dilution rate on metabolic pathway shift between aceticlastic and nonaceticlastic methanogenesis in chemostat cultivation. App/ Environ Microbiol 2004, 70(7):4

17. Fukuzaki S, Nishio N, Nagai S: Kinetics of the methanogenic fermentation of acetate. Appl Environ Microbiol 1990, 56(10):3158-3163.

18. Schnürer A, Zellner $G$, Svensson BH: Mesophilic syntrophic acetate oxidation during methane formation in biogas reactors. FEMS Microbiol Ecol 1999, 29(3):249-261.
19. Hao LP, Lu F, He PJ, Li L, Shao LM: Predominant contribution of syntrophic acetate oxidation to thermophilic methane formation at high acetate concentrations. Environ Sci Technol 2011, 45(2):508-513.

20. Westerholm M, Roos S, Schnurer A: Tepidanaerobacter acetatoxydans sp. nov., an anaerobic, syntrophic acetate-oxidizing bacterium isolated from two ammonium-enriched mesophilic methanogenic processes. Syst App Microbiol 2011, 34(4):260-266

21. Hattori S, Luo H, Shoun H, Kamagata Y: Involvement of formate as an interspecies electron carrier in a syntrophic acetate-oxidizing anaerobic microorganism in coculture with methanogens. J Biosci Bioeng 2001, 91(3):294-298

22. Hattori S, Galushko AS, Kamagata Y, Schink B: Operation of the CO dehydrogenase/acetyl coenzyme A pathway in both acetate oxidation and acetate formation by the syntrophically acetate-oxidizing bacterium Thermacetogenium phaeum. J Bacterio/ 2005, 187(10):3471-3476.

23. Schnürer A, Houwen FP, Svensson BH: Mesophilic syntrophic acetate oxidation during methane formation by a triculture at high ammonium concentration. Arch Microbiol 1994, 162(1):70-74.

24. Müller V: Energy conservation in acetogenic bacteria. Appl Environ Microbiol 2003, 69(11):6345-6353.

25. Gottwald M, Andreesen JR, LeGall J, Ljungdahl LG: Presence of cytochrome and menaquinone in Clostridium formicoaceticum and Clostridium thermoaceticum. J Bacteriol 1975, 122(1):325-328.

26. Hugenholtz J, Ljungdahl LG: Electron transport and electrochemical proton gradient in membrane vesicles of Clostridium thermoautotrophicum. J Bacteriol 1989, 171(5):2873-2875.

27. Pierce E, Xie G, Barabote RD, Saunders E, Han CS, Detter JC, Richardson P, Brettin TS, Das A, Ljungdahl LG, Ragsdale SW: The complete genome sequence of Moorella thermoacetica (f. Clostridium thermoaceticum). Environ Microbiol 2008, 10(10):2550-2573.

28. Poehlein A, Schmidt S, Kaster AK, Goenrich M, Vollmers J, Thurmer A Bertsch J, Schuchmann K, Voigt B, Hecker M, Daniel R, Thauer RK, Gottschalk G, Müller V: An ancient pathway combining carbon dioxide fixation with the generation and utilization of a sodium ion gradient for ATP synthesis. PLoS One 2012, 7(3):e33439.

29. Biegel E, Schmidt S, Müller V: Genetic, immunological and biochemical evidence for a Rnf complex in the acetogen Acetobacterium woodii. Environ Microbiol 2009, 11(6):1438-1443.

30. Kopke M, Held C, Hujer S, Liesegang H, Wiezer A, Wollherr A, Ehrenreich A Liebl W, Gottschalk G, Durre P: Clostridium ljungdahlii represents a microbial production platform based on syngas. Proc Natl Acad Sci USA 2010, 107(29):13087-13092.

31. Kosaka T, Kato S, Shimoyama T, Ishii S, Abe T, Watanabe K: The genome of Pelotomaculum thermopropionicum reveals niche-associated evolution in anaerobic microbiota. Genome Res 2008, 18(3):442-448.

32. Mclnerney MJ, Rohlin L, Mouttaki H, Kim U, Krupp RS, Rios-Hernandez L, Sieber J, Struchtemeyer CG, Bhattacharyya A, Campbell JW, Gunsalus RP: The genome of Syntrophus aciditrophicus: life at the thermodynamic limit of microbial growth. Proc Natl Acad Sci USA 2007, 104(18):7600-7605.

33. Müller N, Worm P, Schink B, Stams AJM, Plugge CM: Syntrophic butyrate and propionate oxidation processes: from genomes to reaction mechanisms. Environ Microbiol Rep 2010, 2(4):489-499.

34. Sieber JR, Sims DR, Han C, Kim E, Lykidis A, Lapidus AL, McDonnald E, Rohlin L, Culley DE, Gunsalus R, Mclnerney MJ: The genome of Syntrophomonas wolfei: new insights into syntrophic metabolism and biohydrogen production. Environ Microbiol 2010, 12(8):2289-2301.

35. Tech M, Merkl R: YACOP: Enhanced Gene Prediction Obtained by a Combination of Existing Methods. In Silico Biol 2003, 3(4):441-451.

36. Carver TJ, Rutherford KM, Berriman M, Rajandream MA, Barrell BG, Parkhill J: ACT: the Artemis Comparison Tool. Bioinformatics 2005, 21(16):3422-3423.

37. Overbeek R, Larsen N, Walunas T, D'Souza M, Pusch G, Selkov E Jr, Liolios K, Joukov V, Kaznadzey D, Anderson I, Bhattacharyya A, Burd H, Gardner W, Hanke P, Kapatral V, Mikhailova N, Vasieva O, Osterman A, Vonstein V, Fonstein M, Ivanova N, Kyrpides N: The ERGO genome analysis and discovery system. Nucleic Acids Res 2003, 31(1):164-171.

38. Markowitz VM, Mavromatis K, Ivanova NN, Chen IM, Chu K, Kyrpides NC: IMG ER: a system for microbial genome annotation expert review and curation. Bioinformatics 2009, 25(17):2271-2278.

39. ExPASy: SIB Bioinformatics Resource Portal. http://expasy.org/.

40. Zdobnov EM, Apweiler R: InterProScan-an integration platform for the signature-recognition methods in InterPro. Bioinformatics 2001, 17(9):847-848. 
41. Tatusov RL, Koonin EV, Lipman DJ: A genomic perspective on protein families. Science 1997, 278(5338):631-637.

42. Schmeisser C, Liesegang H, Krysciak D, Bakkou N, Le Que're' A, Wollherr A, Heinemeyer I, Morgenstern B, Pommerening-Roser A, Flores M, Palacios R, Brenner S, Gottschalk G, Schmitz RA, Broughton WJ, Perret X, Strittmatter AW, Streit WR: Rhizobium sp. strain NGR234 possesses a remarkable number of secretion systems. Appl Environ Microbiol 2009, 75(12):10.

43. Needleman SB, Wunsch CD: A general method applicable to the search for similarities in the amino acid sequence of two proteins. $J \mathrm{Mol} B \mathrm{BiO}$ 1970, 48(3):443-453

44. Carver T, Thomson N, Bleasby A, Berriman M, Parkhill J: DNAPlotter: circular and linear interactive genome visualization. Bioinformatics 2009, 25 (1):119-120.

45. BioCyc Database Collection. http://biocyc.org/.

46. Larkin MA, Blackshields G, Brown NP, Chenna R, McGettigan PA, McWilliam H, Valentin F, Wallace IM, Wilm A, Lopez R, Thompson JD, Gibson TJ, Higgins DG: Clustal W and Clustal X version 2.0. Bioinformatics 2007, 23 (21):2947-2948.

47. Bagos PG, Nikolaou EP, Liakopoulos TD, Tsirigos KD: Combined prediction of Tat and Sec signal peptides with hidden Markov models. Bioinformatics 2010, 26(22):2811-2817.

48. Müller $V$, Bowien S: Differential effects of sodium ions on motility in the homoacetogenic bacteria Acetobacterium woodii and Sporomusa sphaeroides. Arch Microbiol 1995, 164(5):363-369.

49. Horvath $P$, Barrangou R: CRISPR/Cas, the immune system of bacteria and archaea. Science 2010, 327(5962):167-170.

50. Haft DH, Selengut J, Mongodin EF, Nelson KE: A guild of 45 CRISPRassociated (Cas) protein families and multiple CRISPR/Cas subtypes exist in prokaryotic genomes. PLoS Comput Biol 2005, 1(6):e60

51. Westra ER, Brouns SJ: The rise and fall of CRISPRs - dynamics of spacer acquisition and loss. Mol Microbiol 2012, 85(6):1021-1025.

52. Makarova KS, Haft DH, Barrangou R, Brouns SJ, Charpentier E, Horvath $P$, Moineau S, Mojica FJ, Wolf Yl, Yakunin AF, van der Oost J, Koonin EV: Evolution and classification of the CRISPR-Cas systems. Nat Rev Microbio 2011, 9(6):467-477.

53. Röder JC: Syntrophe Oxidation der Fettsäure Acetat und des biogenen Amins Cadaverin (1,5-Diaminopentan) durch definierte methanogene Kokulturen. Thesis: Universität Konstanz; 2010.

54. Frazzon J, Dean DR: Formation of iron-sulfur clusters in bacteria: an emerging field in bioinorganic chemistry. Curr Opin Chem Biol 2003, 7(2):166-173.

55. Gerber J, Lill R: Biogenesis of iron-sulfur proteins in eukaryotes: components, mechanism and pathology. Mitochondrion 2002, 2(1-2):71-86.

56. Wilquet V, Van de Casteele M, Gigot D, Legrain C, Glansdorff N: Dihydropteridine reductase as an alternative to dihydrofolate reductase for synthesis of tetrahydrofolate in Thermus thermophilus. J Bacteriol 2004, 186(2):351-355

57. Zhao G, Xia T, Song J, Jensen RA: Pseudomonas aeruginosa possesses homologues of mammalian phenylalanine hydroxylase and 4 alphacarbinolamine dehydratase/DCoH as part of a three-component gene cluster. Proc Natl Acad Sci USA 1994, 91(4):1366-1370.

58. Martens $\mathrm{JH}$, Barg $\mathrm{H}$, Warren MJ, Jahn D: Microbial production of vitamin B12. Appl Microbiol Biotechnol 2002, 58(3):275-285.

59. Rodionov DA, Vitreschak AG, Mironov AA, Gelfand MS: Comparative genomics of the vitamin B12 metabolism and regulation in prokaryotes. J Biol Chem 2003, 278(42):41148-41159.

60. Raux E, Schubert HL, MJ W: Biosynthesis of cobalamin: a bacterial conundrum. Cell Mol Life Sci 2000, 57(13):1880-1893.

61. Goldman BS, Roth JR: Genetic-Structure and Regulation of the cysG gene in Salmonella typhimurium. J Bacteriol 1993, 175(5):1457-1466.

62. Fazzio TG, Roth JR: Evidence that the CysG protein catalyzes the first reaction specific to B-12 synthesis in Salmonella typhimurium, insertion of cobalt. J Bacteriol 1996, 178(23):6952-6959.

63. Hattori S, Galushko AS, Kamagata Y, Schink B: Operation of the CO dehydrogenase/acetyl coenzyme A pathway in both acetate oxidation and acetate formation by the syntrophically acetate-oxidizing bacterium Thermacetogenium phaeum. J Bacteriol 2005, 187(10):3471-3476.

64. Biegel $\mathrm{E}$, Müller $\mathrm{V}$ : Bacterial $\mathrm{Na}^{+}$-translocating ferredoxin: $\mathrm{NAD}^{+}$ oxidoreductase. Proc Natl Acad Sci USA 2010, 107(42):18138-18142.

65. Schuchmann K, Muller V: A bacterial electron-bifurcating hydrogenase. J Biol Chem 2012, 287(37):31165-31171.
66. Das A, Hugenholtz J, Van Halbeek H, Ljungdahl LG: Structure and function of a menaquinone involved in electron transport in membranes of Clostridium thermoautotrophicum and Clostridium thermoaceticum. J Bacteriol 1989, 171(11):5823-5829.

67. Wohlfarth G, Diekert G: Thermodynamics of methylenetetrahydrofolate reduction to methyltetrahydrofolate and its implications for the energy metabolism of homoacetogenic bacteria. Arch Microbio/ 1991, 155(4):378-381.

68. Huang H, Wang S, Moll J, Thauer RK: Electron Bifurcation Involved in the Energy Metabolism of the Acetogenic Bacterium Moorella thermoacetica Growing on Glucose or H2 plus CO2. J Bacterio/ 2012, 194(14):10.

69. Verhagen MF, O'Rourke T, Adams MW: The hyperthermophilic bacterium, Thermotoga maritima, contains an unusually complex iron-hydrogenase: amino acid sequence analyses versus biochemical characterization. Biochim Biophys Acta 1999, 1412(3):212-229.

70. Schut GJ, Adams MW: The iron-hydrogenase of Thermotoga maritima utilizes ferredoxin and NADH synergistically: a new perspective on anaerobic hydrogen production. J Bacterio/ 2009, 191(13):4451-4457.

71. Welte C, Kallnik V, Grapp M, Bender G, Ragsdale S, Deppenmeier U: Function of Ech hydrogenase in ferredoxin-dependent, membranebound electron transport in Methanosarcina mazei. J Bacteriol 2010, 192(3):674-678.

72. Bagramyan K, Trchounian A: Structural and functional features of formate hydrogen lyase, an enzyme of mixed-acid fermentation from Escherichia coli. Biochemistry 2003, 68(11):1159-1170.

73. Dobbek H, Gremer L, Meyer O, Huber R: Crystal structure and mechanism of $\mathrm{CO}$ dehydrogenase, a molybdo iron-sulfur flavoprotein containing S-selanylcysteine. Proc Natl Acad Sci USA 1999, 96(16):8884-8889.

74. Ragsdale SW, Clark JE, Ljungdahl LG, Lundie LL, Drake HL: Properties of purified carbon monoxide dehydrogenase from Clostridium thermoaceticum, a nickel, iron-sulfur protein. J Biol Chem 1983, 258 (4):2364-2369

75. Ragsdale SW, Ljungdahl LG, DerVartanian DV: Isolation of carbon monoxide dehydrogenase from Acetobacterium woodii and comparison of its properties with those of the Clostridium thermoaceticum enzyme. J Bacteriol 1983, 155(3):1224-1237.

76. Bott $M$, Thauer RK: Proton translocation coupled to the oxidation of carbon monoxide to $\mathrm{CO}_{2}$ and $\mathrm{H}_{2}$ in Methanosarcina barkeri. Eur J Biochem 1989, 179(2):469-472.

77. Ragsdale SW, Pierce E: Acetogenesis and the Wood-Ljungdahl pathway of $\mathrm{CO}_{2}$ fixation. Biochim Biophys Acta 2008, 1784(12):1873-1898.

78. Walsby AE: Gas vesicles. Microbiol Rev 1994, 58(1):94-144.

79. Duine JA, Frank J: The role of $P Q Q$ and quinoproteins in methylotrophic bacteria. FEMS Microbiol Lett 1990, 87(3-4):221-226.

80. Diekert G, Wohlfarth $\mathrm{G}$ : Metabolism of homoacetogens. A VAN LEEUW J MICROB 1994, 66:12.

81. Meijden P, Drift C, Vogels GD: Methanol conversion in Eubacterium limosum. Arch Microbiol 1984, 138(4):360-364.

82. Thauer RK, Jungermann K, Decker K: Energy conservation in chemotrophic anaerobic bacteria. Bacteriol Rev 1977, 41(1):100-180.

83. Sullivan MJ, Petty NK, Beatson SA: Easyfig: a genome comparison visualizer. Bioinformatics 2011, 27(7):1009-1010.

84. Dzioba J, Hase CC, Gosink K, Galperin MY, Dibrov P: Experimental verification of a sequence-based prediction: $F(1) F(0)$-type ATPase of Vibrio cholerae transports protons, not $\mathrm{Na}(+)$ ions. J Bacteriol 2003, 185 (2):674-678.

doi:10.1186/1471-2164-13-723

Cite this article as: Oehler et al:: Genome-guided analysis of physiological and morphological traits of the fermentative acetate oxidizer Thermacetogenium phaeum. BMC Genomics 2012 13:723. 